\title{
Manggarai Speech Community Local Wisdom in Ireng Neka Dur Ata: Preliminary Study of Cultural Ingistics
}

\author{
Katarina Noviming Sakura ${ }^{1}$ \\ Magister Linguistics \\ Faculty of Arts-Udayana University \\ Denpasar \\ noviming.sakura@gmail.com
}

\begin{abstract}
This article aims at describing the local wisdom of Manggarai Speech Community through a form of taboo language called ireng. Ireng is a verbal tradition contains a set of taboo actions that will bring bad luck to those who decide not to obey it. Ireng neka dur ata is the data used on this article. The local wisdom is found through analysis process of value and meaning of ireng neka dur ata. The result shows 5 facts: (1) this ireng contains of lingual unit that are modus of speech, verb choice, and word order, (2) harmony of life is the value taught through this ireng, (3) contextual meaning of this ireng is "do not extrude guest and its consequence of bad luck in economic", (4) the local wisdom found are a habit and a sacrifice of the guest and the host, (5) the obedient to its culture, the effort maintain harmony of life, and serve people above self are reflection of the character of Manggarai Speech Community
\end{abstract}

Index Terms - local wisdom, ireng, cultural linguistics

\section{INTRODUCTION}

If language is seen as a unity of the phenomena of community life, there will be many facts found in the language used by a particular group of community. Local wisdom is one of the cultural elements that can be expressed through language. It is said in KBBI, local wisdom is any form of policy based on the values of goodness that are trusted, applied, and always maintained in a long period of time (for generations) by a group of people in a particular area or environment. Ireng is one of the manifestations of oral tradition that is in Manggarai speech community (hereinafter abbreviated as GTM) and is still in use today. It contains the local wisdom of native speakers which are expressed in the form of special prohibitions. magical things and taboos, which will bring disaster to those who break it. Ireng has existed and been used since the time of the ancestors of Manggarai and was passed on to every generation. Although it is not shaped as a written rule, ireng applies to all ages and community groups. Ireng shows the uniqueness of aspects of the language as well as the Manggarai culture.

This article aims to analyze and describe GTM local wisdom through the values and meanings contained in ireng. Several previous studies on the Manggarai language have been conducted [1][2][3] on traditional rituals and texts, lexicons, and clitics of which the results show the character of GTM as a society that upholds the values of customs. The ireng utterance used as data is neka dur ata (do not reject people) which is a rule or social norm. In linguistics, the relationship between language and culture is mainly studied by cultural linguistics. Therefore, data analysis will be carried out based on the formulations of cultural linguistics, specifically those developed by Palmer.

\section{Materials And Methods}

The development of linguistics as one of the disciplines has coupled with other disciplines to be involved in research and development, for example with the science of psychology that produces psycholinguistics, with cultures that produce linguistic culture, a combination with ecology 
produces ecolinguitics, etc. Cultural linguistics is a combination of linguistics and culture as a frame of mind and perspective in discovering language phenomena [4]. Linguistics of culture specifically examines the relationship of language and culture.

With language, we can record what has happened and we can also state what will happen. In other words, we can pass on culture to future generations. From this it can be said that language functions as a cultural tool [5]. The 3 important pillars in the linguistic culture that Palmer coined were the grammar of the languages of the Boas, ethnosemantic, and speaking ethnography. The three pillars unite the lingual and non-lingual elements of language. Grammar and ethnocentric languages are pillars that focus on lingual elements, while ethnography of speaking refers to the context of speech produced by speakers (non-lingual elements).

The language grammar in Boasian for example classifies nouns into sexes, classifies them as animate / inanimate, and classifies humans / not humans, etc. Ethnosemantics is the study of the ways in which different cultures organize and group fields of science such as plants, animals, and kinship. Ethnosemantics specifically focuses on lexical semantics, such as grouping dogs, wolves, and foxes as canines, while long-haired dogs and large long-haired dogs as dogs (dogs). As for ethnography of speaking, applying linguistic sources for social purposes in situations that are culturally meaningful [1]. Factors that must also be present in the process of delivering messages through language are the factors of mutual understanding or mutual intubility [5]. Saussure states that when speakers begin to speak, there is also a process of mental facts (concepts) that correlate with linguistic-sound (sound-images). These two forms process through the brain. Concept refers to 'something' that will be stated, while sound-images are the embodiment of the concept in the form of language sounds [5]. It is said that the use of the Manggarai language has a system that can be distinguished according to the intent and purpose of use, consisting of the language of everyday conversation, the language of traditional ceremonies, ceremonial prayers that have religious values, sign language, languages symbol, expression and poem [6].

In this case, ireng has certain intentions and methods in the process of transmitting messages from speakers to speakers. The lingual element that is present in Ireng's speech needs to be seen as a unified cultural concept in describing its meaning. The person cannot be interpreted literally, but must consider the non-lingual elements that are present in it.

Palmer offers what is also called imagery. According to him, language is a verbal symbol game based on imagery. Imagery is what we see in our mind's eye, but imagery is also a taste of mangoes, a feeling of walking in the woods, Mississippi Masala music, etc. The imagination that lives in the experience is obtained through the senses, then we speak
[7]. Knowledge of culture is very important to interpret conventional speech forms which are increasingly found in various forms and complex speech structures [7].

Linguistic and cultural unity play role in describing the meaning of ireng, so that ireng is not only an ordinary speech but a meaningful speech that impacts and influences the speaker. The existence of mutual understanding between speakers and speakers is the basis in producing and interpreting ireng's speech.

To express the value and meaning of ireng neka durata (do not reject people), the research is conducted using a descriptive approach in which the results of the study will be described without going through calculations and numbers. The type of data used is oral data obtained through interview methods with recording techniques. Furthermore, the data will be analyzed by first transcribing ireng's speech into the writing, describing the existing lingual units, describing the values and meanings to see the local wisdom of GTM.

\section{Results And Discussion}

Manggarai is now considered as one of the world's tourist destinations, especially in the tourist attractions of Komodo National Park and Wae Rebo. Customary villages. Despite having natural wealth as a source of regional income, Manggarai should be guided by cultural values that have shaped the character of its people. Local wisdom needs to be maintained so that it is not eroded by the time and modernity of the world. Local wisdom that is present through the language in GTM is ireng. It is different from the daily conversation utterances, although there is something happening in the context of everyday situations, it is more of a speech that is used as a life guide to control Manggarai behavior. Ireng is mainly used to prevent bad things from happening in GTM. The sanctions that will be imposed on those who violate them make GTM prefer to obey it.

\section{A. Lingual Unit in Ireng "neka dur ata"}

Although it is part of the culture, this ireng shows lingual features. The first lingual feature is the sentence mode, which is delivered directly without beginning with the magic word or neka rabo 'sorry'. This implies a higher level of speaker power than the addressee. Usually the respondent's response is iyo ite 'yes, father / mother' as a form of response to the approval of Ireng's advice.

The second lingual feature is the selection of encouraging verbs, namely dur. Besides dur, GTM also has cipa and doet to express the meaning of rejecting. But GTM usually uses dur to express this ireng. The lingual feature which is the sentence structure. Neka dur or 'do not reject people' is expressed as it is in the order of meaning.

\section{B. Life Values in the Message "neka dur ata"}

Neka dur ata 'do not reject people' is one of the living things that is still used by Manggarai. It is born as a social 
norm that serves to regulate GTM behavior towards guests who come to visit. The value of life contained in the utterances of Neka Dur or is to respect guests as their own family for the sake of creating harmony of life. The teachings about this sense of family are to be guarded by GTM since the time of its ancestors. This is a GTM treasure in living in a community. Even though the condition of the host is not sufficient in assets and wealth, GTM must serve guests well. GTM is required to offer drinks, food, and provide a place to stay if needed. With their own ways, GTM will make every effort to be a good host despite its shortcomings.

One thing that must be balanced with entertaining guests is sincerity. TM cannot entertain guests while complaining, grumbling, or pouting. GTM must keep smiling kindly, chatting intently, even though they do not know the guest well and even though there is a burden of thoughts about how to treat it when it is lacking. On the other hand, even though they do not know each other, there may be unknown family relationships. This is also the harmony of life that wants to be guarded. Good service for guests will give a good impression for their guests. The kindness of the host will be rewarded at different times and places. Like gravity, there is a law of attraction between good deeds and replies. Ireng neka dur or other implications in the process of maintaining harmony of life, namely the habit of jomel 'greeting people who are passing in front of the house, which aims to invite him to stop by. Usually those who are greeted are neighbors or relatives who pass by, and not infrequently they will actually stop by for a visit.

Jomel is a form of hospitality owned by GTM, also implicitly shows the compliance of GTM towards durian variety. Although there is no excess food or drink at home, GTM still greets and invites people to stop by in an effort to maintain harmony.

In addition, GTM also has other forms of appreciation to guests, namely children or young people who are family members or who live in a house with the host, will eat the most recent after guests and host (husband, wife, parents) eat first. This habit is inherited from generation to generation. The social function implied by this habit is respecting guests and anticipating if food is lacking. It would be better if the host who sacrificed not to eat than guests who did not eat. Automatically, the host will reduce the meal portion so that guests can have more free meals. Or if possible, the host will rush to buy additional food so that everyone can eat enough.

The unique phenomenon that is also present in this visiting situation is that guests also understand the host's position so that guests are in effect not wanting to be troublesome. This is because mutual understanding and understanding of culture must not reject or expel guests who have been taught from generation to generation.

\section{The meaning of Ireng "neka dur ata" that is related to social life}

In general, meaning can be divided into 2, namely lexical meaning and contextual meaning. Lexical meaning is the true meaning possessed by each word, while contextual meaning is meaning that arises based on context when the sentence or speech is produced.

In lexical terms, neka dur ata means discourage others. Dur verb means encouraging ones that cause physical pain for someone, for example pushing into a ravine or into the middle of a highway. But if it is said when a guest visits, then the sentence acts as an ireng which means do not reject guests, or do not expel guests. The process of inheritance is done by explaining the context of the situation which underlies the emergence of this ireng speech so that speakers have the same understanding.

Regarding the value of life to be guarded, neka dur has contextual meaning related to social life. Community life is not only limited to respecting family members at home, neighbors, atmosphere of pain and grief, joy, but also respecting guests who come to visit.

As the guest principally is king, GTM has an obligation to entertain guests well, especially guests who come from far away. Guests must be treated properly or special, even though they are not known.

GTM believes that if this ireng is violated or if the guest is not well received, it will reduce the owner's fortune, even if the provision is lost. Ireng is also preserved by the family of the researchers themselves. Even though guests are unknown and arrive suddenly (early morning, dawn, night, etc.), these guests must be invited in and allowed to stay overnight if needed. Reception is carried out with the awareness that the guest is family and needs help. Implicitly, this ireng also means giving help to those in need.

\section{Conclusion}

From the description of the results above, a number of things can be concluded:

1. The utterances of ireng "neka dur ata" shows lingual features which are the essence of language. The lingual features that are represented are the mode of direct speech, the selection of verbs, and the order of words in the order of meaning.

2. The utterances of Ireng "neka du rata" carry the value of life, which is to maintain harmony among the people.

3. The contextual meaning contained in the ireng "neka du rata" is the meaning related to community life, that is, do not reject guests or do not expel guests. "Neka durata" will only be meaningful as ireng if it is spoken in the context of a suitable situation and there is a common understanding between the speakers. Another implicit meaning is helping each other among people.

4. The local wisdom that is alive and maintained is Jomel and sacrificing themselves / succumbing to eating, in seeking harmony in living in a community.

5. GTM is a cultural community and has an orderly character in its customs, upholds harmony of life, and is not selfish. However, this culture or condition also has the risk that we cannot guess whether visiting guests come with good intentions or not. The house owner must be prepared to risk the loss of goods or other 
Journal of A Sustainable Global South, p-ISSN: 2579-6062

elements of crime that may occur, especially if guests who visit are not known.

\section{REFERENCES}

[1] Erom, Kletus. 2010. Sistem Pemarkahan Nomina Bahasa Manggarai dan Interelasinyaa dengan Sistem Penamaan Entitas: Sebuah Kajian Linguistik Kebudayaan. Denpasar: Disertasi Universitas Udayana.

[2] Dedo, Lutgardis Marni. 2012. Teks Curu Mori Adak Guyub Tutur Manggarai. Denpasar: Tesis Universitas Udayana.

[3] Kanisisus, Rambut. 2015. Bahasa Ritual Barong Wae dalam Dinamika Guyub Tutur Bahasa Manggarai: Sebuah Kajian Linguistik Kebudayaan. Denpasar: Disertasi Universitas Udayana.

[4] Mbete, Aron Meko. 2013. Sekilas tentang Linguistik Kebudayaan. Bahan Matrikulasi Program Magister Linguistik Universitas Udayana.

[5] Pateda, Mansoer. 2011. Linguistik Sebuah Pengantar. Bandung: Penerbit Angkasa.

[6] Hemo, Doroteus. 1988. Sejarah Daerah Manggarai.

[7] Erom, Kletus. 2007. Teori Linguistik Kebudayaan: Terjemahan dari Buku Toward a Theory of Cultural Linguistics oleh Gary B. Palmer. Denpasar. 